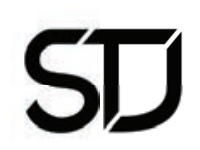

\title{
Is it ethical for a Christian to treat depression with anti-depressants?
}

\author{
Jooste, Simon \\ Stellenbosch University \\ simonjooste@gmail.com
}

\begin{abstract}
In this essay I consider whether it is right for a Christian to use an anti-depressant to treat depression. All human beings are responsible to image God in a moral and dignified manner as mortal creatures living in a broken world. It is not easy to do so in our modern culture of narcissism and therapy, which encourages the abuse of medicine. The calling of the Christian, however, extends beyond the ethics of a common humanity. The disciple of Christ suffers by virtue of living in a fallen world, but also because of her baptism into the death of Christ. Like Jesus, believers suffer first and then find glory. Suffering and death are, paradoxically, God's means of accomplishing and furthering salvation. In light of the body and soul components of depression, and in view of the Christian vocation of suffering, the use of anti-depressants invites careful reflection. In this essay I argue that in some cases it is appropriate to incorporate the likes of Prozac into a holistic approach to treating depression. I set forth my case in four parts. First, I show how depression is part of the plight of humanity broken in body and soul, but not without God's mercy extended through health care and the cross. Secondly, consideration is given to the Christian's call to and benefit from a life of cross-shaped suffering. Thirdly, I argue that the Christian mind must guard against a theology of glory clothed in the therapeutic narcissism of our age. Finally, I set forth a recovery programme grounded in the sacred means of the church and the God-given helps of modern medical science.
\end{abstract}

Key words

Depression; anti-depressants; wisdom; ethics; bioethics; Word and sacraments

\section{Introduction}

Christians suffer in this life. This is due to living in a fallen world, but also because of their cross-bearing identity with Jesus Christ. Depression is one way that believers hurt. The difficulty for Christians - who see humans as 
created both body and soul - is that depression cannot always be neatly traced back to a physiological cause, like for example cancer. There is no definitive empirical test for depression. In other words, a depressed state of being is the result of a complex interplay of the physical and spiritual. Hence, wisdom dictates that the ethics of alleviating depression should consider both its physiological and spiritual dimensions. Furthermore, attention must be given to the moral complexity of treating depression that has increased considerably with the rise of various anti-depressant medication options.

It is beyond the expertise of this author and the scope of this essay to adjudicate ethical questions within the medical community around anti-depressant use. For example: Are anti-depressants more effective than a placebo? In light of relative ignorance about certain aspects of the brain, what are the long-term effects of anti-depressant use? Are doctors over-prescribing anti-depressants due to monetary incentives from big pharmacological companies? (I do not imply that such bioethical questions are morally inconsequential for Christians.)

I, therefore, make four assumptions. First, medical science has shown that our thoughts, feelings and actions are inextricably linked to brain activity. Secondly, advances in medical science have proven anti-depressants relatively safe and effective when administered under doctor supervision and under certain circumstances. Thirdly, anti-depressants alter the chemical balance of the brain to alleviate depression. Fourthly, it is unclear whether anti-depressants change innate personality or inhibit the full range of emotional expression.

In this article I consider whether it is right for a Christian to use an antidepressant to treat depression. All human beings are responsible to image God in a moral and dignified manner as mortal creatures living in a broken world. It is not easy to do so in our modern culture of narcissism and therapy, which encourages the abuse of medicine. The calling of the Christian, however, extends beyond the ethics of a common humanity. The disciple of Christ suffers by virtue of living in a fallen world, but also because of her baptism into the death of Christ. Like Jesus, believers suffer first and then glory. Suffering and death are, paradoxically, God's means of accomplishing and furthering salvation. In light of the body 
and soul components of depression, and in view of the Christian vocation of suffering, the use of anti-depressants invites careful reflection. In this essay I argue that in some cases it is appropriate to incorporate the likes of Prozac into a holistic approach to treating depression. I set forth my case in four parts.

Firstly, I show how depression is part of the plight of humanity broken in body and soul, but not without God's mercy extended through health care and the cross. Secondly, consideration is given to the Christian's call to and benefit from a life of cross-shaped suffering. Thirdly, I argue that the Christian mind must guard against a theology of glory clothed in the therapeutic narcissism of our age. Finally, I set forth a recovery program grounded in the sacred means of the church and the God-given helps of modern medical science. ${ }^{1}$

1 While it is up to the reader to judge, the conclusions of this essay seem compatible with various renderings of a natural theology in general and common grace specifically. My arguments resonate with a recovery and refinement of the historic Reformed two kingdoms and natural law framework for relating Christ and culture in general and treating bioethical questions in particular. While I appreciate the controversial legacy surrounding such theological categories in the South African context, it is beyond the scope of this essay to defend them. At the forefront of the contemporary two kingdoms and natural law renaissance in North America, which has influenced my thinking, see the work of theologian and ethicist, David VanDruen, especially his Natural Law and the Two Kingdoms: A Study in the Development of Reformed Social Thought, Emory Studies in Law and Religion (Grand Rapids: Eerdmans, 2010); Living in God's Two Kingdoms: A Biblical Vision for Christianity and Culture (Wheaton: Crossway, 2010); and David VanDrunen, Divine Covenants and Moral Order: A Biblical Theology of Natural Law (Grand Rapids: Eerdmans, 2014). For my attempt to introduce this framework, via the work of John Calvin and David VanDrunen, into the South African context, see "Recovering the Calvin of "Two Kingdoms?" A Historical Theological Inquiry in the Light of Church-State Discourse in South Africa" (Stellenbosch: SunScholar, 2013), accessed 10 October 2016, http://scholar.sun.ac.za/handle/10019.1/80065. For commentary on how the doctrines of God's two kingdoms, natural law and common grace have been associated with a form of Afrikaner Calvinism underpinning apartheid, see, e.g., John W. de Gruchy, Liberating Reformed Theology: A Sought African Contribution to an Ecumenical Debate (Grand Rapids: Eerdmans, 1991). In my judgment the predominant contemporary perspective of the church in South Africa when it comes to ethics - whether reformed or not; sympathetic to natural theology or not - is one of Christ transforming culture in a redemptive sense. In this approach God is seen as transforming all communities and institutions into the one saving kingdom of Christ; see Jooste "Recovering the Calvin of "Two Kingdoms?" A Historical Theological Inquiry in the Light of Church-State Discourse in South Africa" (Stellenbosch: SunScholar, 2013), accessed 10 October 2016, http://scholar.sun.ac.za/handle/10019.1/80065, Chapter 2.

According to the two kingdoms framework, God rules all of life in his Son, but not all institutions and communities in the same way. Christ rules over the church in a saving 
For the purposes of this essay, "depression" excludes those suffering from a clear separate medical condition such as Alzheimer's and dementia or substance abusers. ${ }^{2}$ Instead, drawing on Scripture and the Diagnostic and Statistical Manual of American Disorders, $5^{\text {th }}$ edition (DSM-V) ${ }^{3}$, depression understood henceforth is a complex interplay of body and soul that significantly impairs an individual's ability to love God, himself and his neighbour as a divine image-bearer. Among the nine symptoms set forth in DSM-V diagnostic criteria, of which at least five must be present for diagnosis, the depressed person may experience weight loss or gain, insomnia, inability to concentrate, fatigue or suicidal thinking. ${ }^{4}$ The presence of such may also be accompanied by or be the cause of an array of maladies with a spiritual dimension, such as an inability to pray coherently, inordinate feelings of guilt or lack of joy.

\section{Sin, suffering and bodily health}

Had Adam not sinned in Paradise he would have entered into a state of eternal embodied bliss. ${ }^{5}$ However, the story did not end that way. Instead, since the Fall of Adam and Eve death and decay have ravaged body and

way and according to the constitution of his Word. The church alone is the preliminary expression of the kingdom of heaven on earth. On the other hand, God rules all other institutions, including the medical profession, as creator and sustainer only in his Son. He governs them according to his universally accessible language of natural law. See generally Living in God's Two Kingdoms: A Biblical Vision for Christianity and Culture (Wheaton: Crossway, 2010). I elaborate further below, albeit generally and briefly, on how the theological underpinnings of God's two kingdoms and natural law apply to the bioethical questions at hand.

2 This category would also include the likes of bipolar disorder and schizophrenia, which assume a degree of neurological deficit. Excluding these illnesses does not imply ambivalence on my part, a lack of moral culpability for the sufferer or the cause having no spiritual component.

3 See American Psychiatric Association and Task Force on DSM-V, Diagnostic and Statistical Manual of Mental Disorders: DSM-V, $5^{\text {th }} e d$. (Washington, DC: American Psychiatric Association, 2013). [Accessed: 8 October, 2016]. http://dsm.psychiatryonline.org/ doi/full/10.1176/appi.books.9780890425596.dsm04

4 See American Psychiatric Association and Task Force on DSM-V, Diagnostic and Statistical Manual of Mental Disorders: DSM-V, $5^{\text {th }}$ edition.

5 See Heidelberg Catechism Q/A 6, 9; translations taken from Psalter Hymnal (Grand Rapids: Board of Publications of CRC, 1976). 
soul. ${ }^{6}$ Things are not the way they were supposed to be. ${ }^{7}$ All of humankind now suffers to some degree.

By the grace of God, life continued east of Eden. Shortly after Adam and Eve's expulsion from the garden, God promised he would recreate a congregation of mankind for heaven. ${ }^{8}$ Yet, while that process of recreation and renewal has been guaranteed and set in motion by the coming of Christ, God's people still await its consummation (Rom. 8:19-25; 2 Cor. 4:16; Rev 21:1-4). In the tension of this already-and-not-yet age, God's people wrestle to make sense of suffering (cf. Job; 2 Cor. 12). In the case of depression, it is assumed to be a function of a mysterious combination of physical and spiritual causes. For we are body and soul creatures. Our humanity constitutes a psychosomatic unity. There is no divide between spirit/mind and matter. ${ }^{9}$ Physical causes stem from living in this fallen world and include innate personalities, fatigue, stress, disease and genetic predisposition. Spiritual causes arise from inhabiting a corrupted world in which one is at once the victim and perpetrator of sinful behaviour. What is more, and of vital importance, there is the reality of God's loving chastisement behind the complex interplay of the physical and spiritual elements of depression (cf. the lament Psalms and Heb. 12:3-11).

In this in-between age, God has provided medical technology as a mercy by which some degree of bodily health can be restored..$^{10}$ It seems reasonable to extend this revitalisation to the treatment of depression. Prozac is a candidate for inclusion here. In other words, God has extended his mercy

6 See Belgic Confession Article 15; translations taken from Psalter Hymnal (Grand Rapids: Board of Publications of CRC, 1976).

7 See generally Cornelius Plantinga, Not the Way It's Supposed to Be: A Breviary of Sin (Grand Rapids; Leicester, Eng.: Eerdmans; Apollos, 1995).

8 See Heidelberg Catechism Q/A 57.

9 See Michael Horton, The Christian Faith (Grand Rapids: Zondervan, 2011), Chapter 12.

10 See David VanDrunen, "What is Christian About Christian Bioethics? A Reformed, Covenantal Proposal," Christian Bioethics 21(3) (2015):337-345, and generally Patrick T. Smith and Fabrice Jotterand, "Toward a Common Grace Christian Bioethics: A Reformed Protestant Engagement with H. Tristram Engelhart, Jr.," Christian Bioethics 20(2) (2014):229-245. For a Reformed rendering of bioethics in South Africa with sympathy toward natural law, but not necessarily the doctrine of two kingdoms, see Jakobus M. Vorster, "The general revelation of God and creational gifts as a source for bioethics,” In die Skriflig 50(1) (2016), a2083, accessed October 15, 2016, http://dx.doi. org/10.4102/ids.v50i1.2083 
to all mankind through the provision of health care, while at the same time bestowing saving mercy upon believers through the gospel. Christians are responsible for making wise use of God's mercies, while at the same time taking up their cross in a broken world bent on idolatrous perversion of the best of God's gifts.

\section{Suffering and spiritual growth}

Suffering in general and depression in particular are not things to be glamorised or sought out as good in isolation. And yet, "[s]uffering is an evil out of which the God revealed in the crucified and risen Jesus can bring good." 11 Thus, we should always be in two minds about it. Suffering can neither be eliminated from human life nor written off as having no purpose. Jesus should be our model here. In Gethsemane Jesus shrank from the suffering that was to come, yet accepted it as part of his calling and obedience (Mt. 26:36-42). ${ }^{12}$ Like Jesus, Christians are called to suffer for the sake of the kingdom (Lk. 9:23; 1 Pet. 1; Js. 1). "The suffering that comes is an evil, but the God who in Jesus has not abandoned us in that suffering can bring good from it for us as for Jesus." ${ }^{13}$

By virtue of his union with Christ, the Christian's life is tied to various forms of suffering (Rom. 8:17; 1 Pet. 1:16). He follows in the footsteps of his Saviour who drank the bitter cup to its dregs so that we might have life. The insignia of the cross, signified and sealed in baptism, is upon every Christian; suffering is a key ingredient to spiritual growth (Job; Ps. 119:67; 1 Pet 1:6-7). Only a regenerate Christian understands the 'foolishness' of a suffering Messiah and the corresponding weakness and despised nature of the Christian life (1 Cor. 1:18ff). The following are some more specific ways in which Scripture reveals the benefits of suffering, which includes depression. ${ }^{14}$

11 See Gilbert Meilaender, Bioethics: A Primer for Christians, $2^{\text {nd }}$ ed. (Grand Rapids, Mich.: W.B. Eerdmans Pub. Co., 2005), p. 7.

12 See Ibid., p. 63.

13 See Ibid.

14 This is not to say that common sense and the nature of things does not point, in a limited way, to the profit of pain. The President's Council for Bioethics points out that sorrow teaches and discontent provokes living in ways we would not otherwise. See President's Council on Bioethics (U.S.) and Kass, Beyond Therapy: Biotechnology and the Pursuit of 
Firstly, suffering tends to deepen repentance by striping the Christian of self-sufficiency and in turn exercises the muscle of faith (Rom. 7-8:1; 2 Cor. 1:6; 12:9). Secondly, God uses suffering to produce an obedient faith in the believer (Js. 1:2-4; Rom. 5:3-5). Suffering not only fashions the fruit of the Spirit individually, but benefits the local church at large: providing opportunities to love and be loved..$^{15}$ Thirdly, suffering teaches the believer about the already-not-yet tension of the Christian life. Fourthly, and by way of summary, suffering teaches the Christian to look away from the fleeting pleasures of this world and live for God's glory and his enjoyment, under his providential care (Ps. 73; 2 Tim. 2:10) ${ }^{16}$. Christians are cross-bearing pilgrims and exiles in this world with a heavenly citizenship (Col. 3:1-4; 1 Peter 2; Heb. 11:1). While at the same time they are also called by God to contribute to and benefit from the fruits of common culture alongside unbelievers (1 Pet. 1-2; Gen. 8-9; Rom. 13).

However, because of the temptations of the world, the flesh and the devil, the Christian is not immune from believing the world's script when it comes to suffering.

\section{Looking for heaven on earth: navigating a culture of therapeutic narcissism}

The proclamation of the crucified Christ and the cost of Christian discipleship is folly to the world. This is because the world, especially western culture, naturally gravitates towards a theology of glory. ${ }^{17}$ Whether atheist or not, most forms of modern western spirituality exalt human autonomy to the exclusion of God, excuse sin and shun suffering. Accordingly, there is an attraction to a medical model that reduces emotional experience and

Happiness, pp. 258-60. See also generally Eric G. Wilson, Against Happiness: In Praise of Melancholy, $1^{\text {st }}$ ed. (New York: Farrar, Straus and Giroux, 2008).

15 See Joel Shuman and Brian Volck, Reclaiming the Body: Christians and the Faithful Use of Modern Medicine, ed. David S. Cunningham and William T. Cavanaugh. The Christian Practice of Everyday Life (Grand Rapids: Brazos Press, 2006), pp. 41-62.

16 See Heidelberg Catechism Lord's Day 1.

17 It is assumed that the theologies of the cross and glory arise as categories from Scripture and every person is an adherent of one or the other; see generally Walther von Loewenich, Luther's Theology of the Cross (Minneapolis: Augsburg Pub. House, 1976) and Michael S. Horton, Too Good to Be True: Finding Hope in a World of Hype (Grand Rapids: Zondervan, 2006). 
well-being to mere biology: the a-moral firing of neurons or secretions of serotonin. In this view, man is just another soul-less animal in a morally indifferent universe, having power to re-create, the ability to write his own script. ${ }^{18}$ With moral straps loosened, the sky is the limit for experiencing 'happiness' in this life. This has led some to describe the ethic of the age as one of pragmatic narcissism (longing for a state of bliss): the triumph of the therapeutic. ${ }^{19}$ Practical success is a suffering-free and pleasure-filled individual experience. ${ }^{20}$ Prozac can become yet another form of therapy for tangible existential results. Neither practitioner nor patient remains unaffected by the spirit of this age. ${ }^{21}$

\section{Re-defining illness}

Coupled with the tendency in modern psychiatry to locate mental/ emotional malfunctions in the body alone, the narcissistic push for

18 See Algis Valiunas, "Sadness, Gladness-and Serotonin," Commentary 121, no. 1 (2006): 62. In this view, even if spiritual impulses or issues of the heart are cited as causes for our actions, they cannot surely be the cause of bad behaviour, for man is naturally good.

19 See Horton, Too Good to Be True: Finding Hope in a World of Hype, p. 51. Writing on the therapeutic age in which we live, Philip Reiff described it as having individual well-being as an end in itself, "rather than a by-product of striving after some superior communal end" thus shifting focus "toward a human condition about which there will be nothing further to say in terms of the old style of despair and hope" (Philip Rieff, The Triumph of the Therapeutic: Uses of Faith after Freud, $1^{\text {st }}$ ed. (New York: Harper \& Row, 1966), p. 261). The therapeutic sensibility can be further explicated as that "feeling, the momentary illusion, of personal well-being, health, and psychic security"; see Christopher Lasch, The Culture of Narcissism: American Life in an Age of Diminishing Expectations (New York: W.W. Norton \& Company, 1991), p. 7. For an example of a more updated critique of the the modern western culture of narcissism, see generally Jean M. Twenge and W. Keith Campell, The Narcissism Epidemic: Living in the Age of Entitlement (New York: Atria, 2010).

20 See generally Rieff, The Triumph of the Therapeutic: Uses of Faith after Freud.

21 Gilbert Meilaender notes that there once was a time when physicians reflected on the moral meaning of their practice. However, the moral meaning of health and medicine has become increasingly secularized, "driven by the view that public consensus must exclude the larger questions about human nature and destiny that religious belief raises" (a minimalist approach). Public policy and medical opinion is shaped as a result; see Meilaender, Bioethics: A Primer for Christians, p. xi. It has also been observed that the efficacy of antidepressants has also skewed professional thinking; see John Stapert, "Curing an Illness or Transforming Self? The Power of Prozac," Christian Century, no. July 13-20 (1994): 685. For bibliographic sources on forces shaping the thinking of the medical community, see President's Council on Bioethics (U.S.) and Kass, Beyond Therapy: Biotechnology and the Pursuit of Happiness, pp. 313-28. 
pleasurable well-being invariably widens the diagnostic pool for so-called mental and other illnesses. Accordingly, health and wholeness looks and feels something like how the World Health Organisation put it in 1946: "a state of complete physical, mental and social well-being, and not merely the absence of disease or infirmity." ${ }^{22}$ Indicative of this trend in recent decades is the work of Dr. Peter D. Kramer, who has argued categorically that depression is an illness rooted in the physiology of the brain alone. In his book, Against Depression, he campaigns to eradicate depression altogether, just as medicine once eradicated smallpox. ${ }^{23}$ While some forms of depression may have physical roots, Kramer is illustrative of a trend toward labelling every form of sadness as sickness (and thus eligible for the likes of Prozac). Accordingly, appropriate grief over the passing of a loved one is now considered a form of illness that must be medicated. ${ }^{24}$ Likewise, healthy mourning over sin is considered questionable. ${ }^{25}$ The medical community and its view of self are threatening to redefine normal emotions and temperament. But for the limits of medical advance, every effort is made to reshape and reform all those who fall short of complete well-being - if not make them better than well. ${ }^{26}$

\section{The happy and triumphant self}

Organically related to the redefinition of illness and drawing upon the same a priori assumptions is the leveraging of Prozac for re-creating the

22 As quoted in Meilaender, Bioethics: A Primer for Christians, p. 44.

23 See Peter D. Kramer, Against Depression (New York: Viking, 2005). See also Ordinarily Well: The Case for Antidepressants (New York: Farrar, Straus and Giroux, 2016) and Listening to Prozac (New York, N.Y., U.S.A.: Viking, 1993). Kramer is too quick to dismiss the spiritual dimension of depression, and how the physical and spiritual feed off each other. In addition, he opens the door to Prozac usage by those not mentally ill but looking to improve their "quality" of life.

24 I realise that what constitutes "appropriate" grieving is culturally determined and that excessive and prolonged grief is not normal, and might warrant medical intervention.

25 The danger of the "medicalization of self-understanding" are dissolving the soul into the body and emptying suffering of its spiritual significance (thus stripping the individual of moral responsibility). With the effectiveness of antidepressants, there is a tendency to "redefine, in medical and biological terms, what are currently considered normal emotions, moods, and temperaments"; see President's Council on Bioethics (U.S.) and Kass, Beyond Therapy: Biotechnology and the Pursuit of Happiness, pp. 266-68.

26 As quoted in Meilaender, Bioethics: A Primer for Christians, p. 44. 
happy and triumphant self, for better personal performance. With drugs like Prozac and more powerful ones on the horizon, comes the possibility of designer personalities through cosmetic psychopharmacology. ${ }^{27}$ As supposed 'masters and possessors of nature,' man is able to refashion parts of his psyche that don't suit him. ${ }^{28}$ Thus, for example, the under-endowed melancholy personality potentially gets a sanguine boost from Prozac.

A close cousin to the above modern current is something socially akin to steroid use in the athletic arena. Like athletes who soar above their natural abilities through the use of anabolic steroids, Prozac is arguably being used in some instances to enhance individual performance in society. Society defines optimal performance as emotionally upbeat resilience and pressures its members to conform accordingly (for a happy and pleasurable existence). ${ }^{29}$ As a result, the accounting clerk looks to Prozac to avoid emotional dips on the job and better position herself for making manager one day. The mother of three turns to Prozac because society has no place for an anxious and frazzled, let alone depressed, individual. Prozac becomes the magic pill to meet the peer pressure of society: the collective drive for establishing heaven on earth. ${ }^{30}$

\section{Toward restoration by sacred and common means}

The Christian is not to be conformed to the world's pattern of thinking (Rom. 12:2). Yet, it is particularly tempting to bow the knee to the pharmacological fruits for therapeutic narcissism and its pragmatic ethics, especially when the billows of suffering roll in. Prozac can be a tempting

27 See David Degrazia, "Prozac, Enhancement, and Self-Creation." In The Hastings Report (2000), p. 2.

28 See Valiunas, "Sadness, Gladness-and Serotonin," p. 62.

29 See Stapert, "Curing an Illness or Transforming Self? The Power of Prozac," p. 686. See also "The Happy Self and the Good Society" in President's Council on Bioethics (U.S.) and Kass, Beyond Therapy: Biotechnology and the Pursuit of Happiness, pp. 266-68.

30 Space does not permit a detailed exploration into the effects that modern western society has on the emotional well-being of an individual. In addition to alienating the emotionally "unwholesome", society makes emotional stability increasingly more difficult as foundational structures of family, work, time/ space, and community become "liquefied"; see Zygmunt Bauman, Liquid Modernity (Cambridge, Malden, MA: Polity Press; Blackwell, 2000). For similar social commentary, see, e.g., Wendell Berry, Sex, Economy, Freedom \& Community: Eight Essays (New Work: Pantheon, 1992). 
easy fix. So where does the depressed Christian look for restoration? In contrast to evangelicalism and Protestant liberalism, rooted in pietistic tendencies toward moralistic subjectivism and social activism, confessional Reformed piety has centred Christian vitality around churchly ordinances administered publicly on the Lord's Day. ${ }^{31}$ In addition to providing sustenance for weary pilgrims, the official ministry of the Word provides essential wisdom in making use of God-given common medical care.

\section{Ministry of Word and sacrament in the covenant community}

Historically Reformed believers have believed and confessed that through Christ's ordinances, especially the Word and Sacraments, God communicates the benefits of redemption to his afflicted people. ${ }^{32}$ Chiefly by the Word preached, the depressed are persevered and perfected through faith unto salvation. ${ }^{33}$ This ministry of proclamation should include the whole counsel of God, both law and gospel, command and promise. For example, through the preaching of the law the sinner who is downcast at failed attempts at self-justification "bottoms out" and finds new life and joy in the gospel. ${ }^{34}$ The command to abstain from sexual immorality rouses the fornicating covenant child to flee to Christ for cleansing and power to fight temptation. And the depressing weight of guilt lifts. The slothful teen enveloped by a cloud of melancholy finds some sunshine after being convicted of his self-abuse through poor eating, sleeping and exercise habits. The retrenched father of four finds renewed resilience and joy after hearing a sermon on Job. This enables him to pray, meditate and look for employment again. Ideally, through the ministry of the law the masks of sin and self-reliance are removed. And in turn through the gospel the saints find their new identity and happiness in Christ.

31 See generally Darryl G. Hart, Calvinism: A History (New Haven: Yale University Press, 2013) and The Lost Soul of American Protestantism (New York: Rowan and Littlefield, 2004), pp. 169-186.

32 See, e.g., Heidelberg Catechism Lord's Day 25 and Belgic Confession Articles 28-35.

33 See Canons of Dordt, Chapter 5, Article 14; translation taken from Psalter Hymnal (Grand Rapids: Board of Publications of CRC, 1976) and Heidelberg Catechism Q/A 65.

34 See Paul's movement from law to gospel in Romans 6-8. 
Knowing our weakness God has also given his church tangible signs and seals to assure us of the Word of promise proclaimed to our ears. In Baptism the depressed are assured of their in grafting into Christ, which includes a lifetime of suffering, but followed by glory. ${ }^{35}$ Through participation in the Eucharist, the depressed feed unto spiritual nourishment and growth in grace. ${ }^{36}$

In turn, having received God's gifts of grace, the covenant community now serves by becoming a balm of comfort to the distressed - each member doing his and her part. ${ }^{37}$ In accordance with the Word, the elders are to pray over the depressed (Js. 5:14-15). The minister, as the trained physician of the soul, ${ }^{38}$ is to be sought out for private counsel and prayer. The community of saints is called to show compassion and carry the burdens of the weak (Gal. 6:2; 2 Cor. 1:4). ${ }^{39}$

In short, the Christian community, both in its official ministerial capacity and broader fellowship, provides cruciform wisdom for approaching suffering and the alleviation of it. While incorporating the moral reflection of the medical establishment servicing humanity at large, the Christian will nevertheless also take into consideration unique angles on life, health and death, provided by Scripture. In other words, redemption in Jesus Christ adds vital contours to the believer's moral reflection on depression and ways of treating it. In keeping with the counter-cultural layer of ethical responsibility set forth in the likes of the Beatitudes, which includes turning the cheek when wronged (Mt. 5:38-42), Christian identity

35 See Heidelberg Catechism Lord's Day 26 and Romans 6-8.

36 See Heidelberg Catechism Lord's Days 28-29.

37 See Heidelberg Catechism Lord's Day 21.

38 This is not to imply that the pastor will have no insights into the broader human condition. A seasoned minister will invariably have a measure of wisdom informed by both Scripture and observations gleaned from the created order at large (see the book of Proverbs generally). While his expertise lie in the former, an ordained minister's baseline proficiency in the latter proves important in handling difficult pastoral cases like depression, which involve knowledge of the body and soul.

39 There are no doubt other things that the body of Christ can do for a depressed individual. Such include singing of psalms and hymns to lift the spirits, just being present during difficult times, and meeting physical needs (like providing meals). Ed Welch has provided some very helpful personal spiritual exercises to help combat depression in Edward Welch, Depression: A Stubborn Darkness - Light for the Path (Winston-Salem: Punch Press, 2004). 
reinterprets suffering of all kinds, including depression, in a new salvific light (see above). Hence, Christians must wrestle with treatment options for depression accordingly. ${ }^{40}$

Some, who avail themselves of the spiritual means offered by the church, may invariably emerge from the pit of depression. Through the ministry of the Word, roots of sinful thinking and behaviour are exposed, helpful wisdom is imparted or the season of spiritual testing passes. However, for others, no matter how pious, may continue to linger in the valley, thereby suggesting ongoing underlying neurochemical causes and/or effects.

At this point, to deny a believer the possibility of antidepressant treatment is to deny that a given case of depression may have a cause in and/or effect on brain chemistry. It is imperative that the church does not unwittingly exacerbate the suffering of the depressed under the guise of a hypersupernaturalism or spirituality that treats all physiochemical problems as spiritual maladies to be treated with spiritual solutions. ${ }^{41}$ The Christian is to avoid both a materialist and spiritual reductionism when it comes to the treatment of depression.

40 From this vantage point of the Word of God and the church that it creates, one can speak of a distinctively Christian bioethics. The claims of this essay resonate with the work of David VanDrunen, who has filled out the notion of a Christian bioethics through his refinement of a two kingdoms and natural law rubric. In short, this unique bioethics is dictated by the believer's profession of Christ and God's covenant of grace. While not discounting the moral insights of the civil kingdom (see fn. 43 below) in which she also participates, the Christian's attitude, moral reflection and action around matters of life, health and death are profoundly shaped by the cross and the beatitude of the kingdom of heaven inaugurated by the New Covenant. One way in which the Word (the constitution of Christ's heavenly or redemptive kingdom) radically re-orients the believer's outlook on life is to see suffering refracted through the salvific lens of the cross. Hence, whenever a Christian is confronted with suffering, like depression, the challenge is to act in a wise and moral way that does justice to his dual citizenship in God's two kingdoms: the redemptive and the civil, the church and all other institutions. See generally VanDrunen, What Is Christian about Christian Bioethics? A Reformed, Covenantal Proposal.

41 For a more moderate example of this spiritual reductionism is an approach to an approach in North America called Nouthetic Counselling (see www.nouthetic.org). A popular publication by its founder, Jay E. Adams, is The Christian Counselor's Manual (Grand Rapids, Mich.: Baker Book House, 1986). At the more extreme end is supernaturalism and tendency of the modern Pentecostal movement. 


\section{Sanctified wisdom using common means}

Just as God uses the churchly means of Word and sacraments to justify and sanctify sinners, he also uses all kinds of broader social means to uphold and sustain a common humanity. Like civil government, the institution of medicine is providentially used by God to extend a measure of health care to all humanity where no-one escapes the atrophy of aging and death. ${ }^{42}$

Before considering medical intervention, wisdom dictates that there are some reasonable and practical avenues to explore first. A minister, friend or doctor may notice issues of general health, personality or lifestyle that could be causing, if not exacerbating, depression. For example, stress and lack of adequate rest can lead to a dejected spirit. Poor diet and lack of exercise has been known to cause, if not accentuate, the "blues." Chronic pain can colour one's world in shades of grey. In addition, a difficult job or living arrangement can be the culprit of depression. Hence, a change in lifestyle, to the degree one is able, or a trip to the doctor to uncover hypothyroidism may help lift depression..$^{43}$ For some, however, the black cloud still remains.

In the same way that God uses means - including the very physical (cf. Sacraments) - for spiritual growth, He has also mercifully made medicine such as Prozac available for our temporal bodily well-being. ${ }^{44}$ Doctors are

42 See Belgic Confession Article 8 and Horton, Christian Faith, Chapter 11. Such claims can also be amplified further through the organising theological lens of God's two kingdoms and natural law. Along these lines, VanDrunen recently defended the idea that a common bioethic (alongside of the notion of a distinct Christian bioethic) is God's provision to all humanity under the terms of the Noachian covenant, which is concerned with the survival and expansion of the human race. Under this universal and non-redemptive covenant, which is a function of God's common grace governance of the world, institutions like the state and medical-care are commissioned to serve the non-saving - yet moral - cultural ends of God's civil kingdom. In this provisional kingdom, the language of moral discourse is not distinctly Christian, but rather depends on insights (albeit imperfect and not necessarily always correctly attributed to God) drawn from God's natural law inscribed on the hearts of all human beings created in God's image. See generally VanDrunen, What Is Christian about Christian Bioethics? A Reformed, Covenantal Proposal.

43 Proverbs and Ecclesiastes provide practical wisdom for living. Among other things, diligence is rewarded and ceaseless toil to be avoided (Prov. 10:4; 12:27; 13:4; Eccl. 2:11, $22 ; 4: 6$.) It is assumed that a psychologist or psychiatrist may be sought out (alongside the care and the counsel of the church session).

44 The Bible is not to be read as a medical journal or a comprehensive reference for solving all issues of medical ethics. Some have taken a Biblicist approach to medical ethics 
to be sought out as God-ordained physicians of the body. ${ }^{45}$ Consideration of Prozac assumes the depressed individual is making every effort to be 'in the way of' spiritual means and has explored the common sense avenues already mentioned above. ${ }^{46}$ Of preliminary importance, are some more pragmatic matters surrounding the administration of the likes of Prozac? For example, the side effect/s of taking Prozac may be so adverse that to continue would be irresponsible. ${ }^{47}$ Another concern is the cost of the drug. If an individual does not have health insurance, it may not be wise to take on the financial burden of paying for the medication. ${ }^{48}$

In addition to these less theoretical considerations, sanctified reason dictates that an individual prescribed Prozac be monitored by the church, family and broader covenant community. With the ethical contours of spiritual vitality mentioned above in mind, certain critical questions arise. Such include: Is Prozac an accomplice to numbing the conscience to sin and encouraging self-sufficiency instead of a life of faith? Is Prozac increasing the temptation to bear fruits of the flesh (direct violations of God's law) instead of fruits of the Spirit (virtue)? Is Prozac helping obscure the reality of the Christian life as being one of suffering and cross bearing? Is Prozac inhibiting a person to love God and his neighbour, and thus bring glory to the Lord?

and in so doing ignored the wealth of knowledge to be harvested from the common grace realm to the detriment of the sick (see John M. Frame, Medical Ethics: Principles, Persons, and Problems (New Jersey: P \& R, 1988). For those concerned about how the likes of Prozac can potentially alter one's state of mind (elevate mood), it is interesting to note that the stimulating effect of caffeine is generally considered permissible. What is more, the Bible encourages "strong drink for the one who is perishing, and wine to those in bitter distress" so that they might "remember their misery no more" (Prov. 31:4-7; cf. Eccl. 9:7; 10:19.)

45 Though, no doubt a believing doctor will ideally have some familiarity with the spiritual side of depression in order to handle a Christian case appropriately. For example, determining how and when to involve pastoral counsel.

46 I realize that a suicidal individual may make a profession of faith but have a sparse history of churchgoing and lead a destructive lifestyle. In this case, the individual may need Prozac for immediate stabilization, if not hospitalization.

47 For example: some patients experience an inability to sleep well while on Prozac. Most doctors would work with a patient until a drug with the most tolerable combination of side effects is found.

48 Again, if the individual is suicidal, cost should not be a factor. The church deaconate, family, or friends might be sought out for financial aid. 
The complexity of depression and the psychosomatic effect of Prozac require much thoughtful reflection and prudence on behalf of both the depressed and loved ones. While there is no formula and each individual case of depression is unique, over time it may become apparent that spiritual renewal is being hindered to such an extent that a reduction in dosage, if not discontinuation of Prozac altogether, is called for. ${ }^{49}$ On this note, and of foremost importance, is the Christian responsibility to evaluate anti-depressant treatment in view of the cruciform and eschatological realities that life, health and death are not ultimate. This tension raises the possibility of abbreviating or even foregoing an anti-depressant altogether, despite the potential resultant ongoing suffering.

In certain cases, Prozac can be a mercy from God to help alleviate the incapacitating physical and spiritual symptoms that accompany depression, while allowing the spiritual life to flower once again. As one remembers that the physical and spiritual are intertwined, hope is that Prozac can help the depressed mother get out of bed for church on Sunday, the father of handicapped children concentrate sufficiently on the clock (to keep his job), and the ex-POW to sleep through the night. In other words, Prozac can aid an individual in returning to a base-line of functionality again: a state of being where faith is freed once again to feel the symphony of emotions found in the Psalms, to love one's neighbour, to have the capacity to suffer when called upon, and to prayerfully orient one's life to the glory of God. Prozac is neither the gospel nor a means of grace. ${ }^{50}$ With time, hopefully Prozac may be discontinued, if not the dosage reduced. ${ }^{11}$ Ideally, Prozac is neither the first line nor the long-term source of restoration for the depressed. ${ }^{52}$

49 For suicidal individuals and those with severe (excessive) bodily symptoms associated with depression, continuation of Prozac, even in light of spiritual "loss", is the way of wisdom. In this instance the higher good is to be pursued.

50 It is one thing to supplant the gospel with Prozac and quite another for someone to admit he needs something to make him well enough to pray; see Gordon Marino, "The Pharmaceutical Option: Job on Prozac," Christian Century 120, no. 16 (2003).

51 Granted there is oversight from a doctor.

52 I realize there will be exceptions. Prozac might need to be administered immediately for the suicidal and a highly traumatized individual may require long-term treatment. 


\section{Conclusion}

Ethical questions around the use of anti-depressants require careful answers from Christians. As God's image-bearers living in a broken world, we suffer in body and soul. In turn, the remedies for our pain cannot always be easily slotted as physical or spiritual. What is more, Scripture makes suffering a critical feature of Christian identity as well integral to the accomplishment of salvation. Therefore, I have tried to demonstrate that ethical reflection around the use of anti-depressants requires both common and cruciform wisdom. While the depressed believer may indeed emerge from the dark abyss without medical intervention, invariably some do not. In such cases, the disciple needs manna from heaven and medicine, the means of grace and an anti-depressant.

Ethical tension and debate around a Christian's use of anti-depressants are indicative of numerous other difficult ethical questions facing the church in a technologically advancing and increasingly secularised post-Apartheid South Africa. Do we as Christians have the Biblical and theological categories to provide wise answers to questions around matters ranging from stem-cell research to casting a political vote? If it is true that the Bible does not have specific answers to all of life's problems. Then, could it be that adjudicating the moral insights and practical goods offered by medical science and other fields of human culture are best done through a re-appropriation of a kind of natural theology rooted in God? More specifically: through the updated and refined rubric of God's natural law and two kingdoms?

\section{Bibliography}

Adams, Jay Edward 1973. The Christian Counsellor's Manual. Grand Rapids, Mich: Baker Book House.

American Psychiatric Association and American Psychiatric Association Task Force on DSM-V. Diagnostic and Statistical Manual of Mental Disorders: DSM-V. $5^{\text {th }}$ ed. Washington, DC: American Psychiatric Association, 2013. Accessed: 8 October 2016. http://dsm.psychiatryonline. org/doi/full/10.1176/appi.books.9780890425596.dsm04 
Bauman, Zygmunt 2000. Liquid Modernity. Cambridge, Malden, MA: Polity Press; Blackwell.

Berkhof, Louis 1969. Systematic Theology. $4^{\text {th }}$ rev. and enl. ed. Grand Rapids: Wm. B. Eerdmans.

Berry, Wendell 1992. Sex, Economy, Freedom \& Community: Eight Essays. New Work: Pantheon.

Calvin, Jean 2006. Institutes of the Christian Religion. Translated by Ford Lewis Battles. Edited by John T. McNeil. Two Volumes. The Library of Christian Classics. Philadelphia: Westminster John Knox Press.

Degrazia, David 2000. “Prozac, Enhancement, and Self-Creation.” In The Hastings Report, 34-40.

De Gruchy, John W 1991. Liberating Reformed Theology: A South African Contribution to an Ecumenical Debate. Grand Rapids: Eerdmans.

Frame, John M 2004. Medical Ethics: Principles, Persons, and Problems. New Jersey: P \& R.

Hart, Darryl G 2004. The Lost Soul of American Protestantism. New York: Rowan and Littlefield Publishers, Inc., 2004.

Hart, Darryl G 2013. Calvinism: A History. New Haven: Yale University Press.

Horton, Michael S 2006. Too Good to Be True: Finding Hope in a World of Hype. Grand Rapids: Zondervan.

Joel Shuman and Brian Volck, M.D. 2006. Reclaiming the Body: Christians and the Faithful Use of Modern Medicine. Edited by David S.

Cunningham and William T. Cavanaugh, The Christian Practice of Everyday Life. Grand Rapids: Brazos Press.

Jooste, Simon N 2013. "Recovering the Calvin of "Two Kingdoms?" A Historical Theological Inquiry in the Light of Church-State Discourse in South Africa". Stellenbosch: SunScholar, 2013. Accessed 10 October 2016, http://scholar.sun.ac.za/handle/10019.1/80065

Kramer, Peter D 2016. Ordinarily Well: The Case for Antidepressants. New York: Farrar, Straus and Giroux. 
Kramer, Peter D 2005. Against Depression. New York: Viking.

Kramer, Peter D 1997. Listening to Prozac. New York, N.Y., U.S.A.: Penguin.

Kuyper, Abraham 1931. Lectures on Calvinism. Grand Rapids, Mich.: Eerdmans.

Lasch, Christopher 1991. The Culture of Narcissism: American Life in an Age of Diminishing Expectations. New York: W.W. Norton \& Company.

Marino, Gordon. “The Pharmaceutical Option: Job on Prozac." Christian Century 120, no. 16 (2003): 18-20.

Meilaender, Gilbert 2005. Bioethics: A Primer for Christians. $2^{\text {nd }}$ ed. Grand Rapids, Mich.: W.B. Eerdmans Pub. Co.

Plantinga, Cornelius 1995. Not the Way It's Supposed to Be: A Breviary of Sin. Grand Rapids, Mich.; Leicester, England: Eerdmans; Apollos.

President's Council on Bioethics (U.S.), and Leon Kass 2003. Beyond Therapy: Biotechnology and the Pursuit of Happiness, $1^{\text {st }}$ edition. New York: Regan Books.

Psalter Hymnal: Doctrinal Standards and Liturgy of the Christian Reformed Church 1976. Grand Rapids: Board of Publications of the CRC.

Rieff, Philip 1966. The Triumph of the Therapeutic; Uses of Faith after Freud. $1^{\text {st }}$ ed. New York: Harper \& Row.

Stapert, John. "Curing an Illness or Transforming Self? The Power of Prozac." Christian Century, no. July 13-20 (1994): 684-87.

Smith, Patrick T. and Jotterand, Fabrice. “Toward a Common Grace Christian Bioethics: A Reformed Protestant Engagement with $\mathrm{H}$. Tristram Engelhart, Jr." In Christian Bioethics 20(2) (2014): 229-245.

Twenge, Jean M. and Campell, Keith W 2010. The Narcissism Epidemic:

Living in the Age of Entitlement. New York: Atria.

Valiunas, Algis. “Sadness, Gladness-and Serotonin.” Commentary 121, no. 1 (2006): 59-63. 
VanDrunen, David 2014. Divine Covenants and Moral Order: A Biblical Theology of Natural Law. Grand Rapids: Eerdmans.

VanDrunen, David 2010. Living in God's Two Kingdoms: A Biblical Vision for Christianity and Culture. Wheaton: Crossway.

VanDrunen, David 2010. Natural Law and the Two Kingdoms: A Study in the Development of Reformed Social Thought, Emory Studies in Law and Religion. Grand Rapids: Eerdmans.

VanDrunen, David. "What is Christian about Christian Bioethics? A Reformed, Covenantal Proposal." In Christian Bioethics 21(3) (2015): 334-355.

VanDrunen, David 2009. Bioethics and the Christian Life: A Guide to Making Difficult Decisions. Wheaton: Crossway.

Von Loewenich, Walther 1976. Luther's Theology of the Cross.

Minneapolis: Augsburg Pub. House.

Vorster, Jakobus M. “The general revelation of God and creational gifts as a source for bioethics.” In die Skriflig 50(1) (2016), a2083. http://dx.doi. org/10.4102/ids.v50i1.2083 Accessed: October 15, 2016.

Welch, Edward 2004. Depression: A Stubborn Darkness - Light for the Path. Winston-Salem: Punch Press.

Welch, Eward T 1998. Blame It on the Brain? Edited by Susan Lutz, Resources for Changing Lives. Phillipsburg: P \& R Publishing.

Wilson, Eric G 2008. Against Happiness: In Praise of Melancholy, $1^{\text {st }}$ edition. New York: Farrar, Straus and Giroux. 